\title{
The dichloromethane extract of the ethnomedicinal plant Neurolaena lobata inhibits NPM/ALK expression which is causal for anaplastic large cell lymphomagenesis
}

\author{
CHRISTINE UNGER ${ }^{1}$, RUXANDRA POPESCU ${ }^{4}$, BENEDIKT GIESSRIGL $^{1}$, DANIELA LAIMER ${ }^{1}$, \\ SUSANNE HEIDER $^{1}$, MAREIKE SEELINGER ${ }^{1}$, RENE DIAZ $^{5}$, BRUNO WALLNÖFER ${ }^{6}$, GERDAEGGER ${ }^{1}$, \\ MELANIE HASSLER ${ }^{1}$, MARTIN KNÖFLER $^{2}$, LEILA SALEH $^{2}$, EMINE SAHIN $^{7}$, MICHAEL GRUSCH $^{7}$, \\ MONIKA FRITZER-SZEKERES ${ }^{3}$, HELMUT DOLZNIG ${ }^{8}$, RICHARD FRISCH ${ }^{5}$, \\ LUKAS KENNER $^{1}$, BRIGITTE KOPP ${ }^{4}$ and GEORG KRUPITZA ${ }^{1}$
}

\begin{abstract}
${ }^{1}$ Clinical Institute of Pathology, ${ }^{2}$ Department of Obstetrics and Fetal-Maternal Medicine, Reproductive Biology Unit and ${ }^{3}$ Clinical Institute of Medical and Chemical Laboratory Diagnostics, Medical University of Vienna, Waehringer Guertel 18-20;

${ }^{4}$ Department of Pharmacognosy, University of Vienna, Althanstrasse 14, Vienna, Austria; ${ }^{5}$ Institute for Ethnobiology, Playa Diana, San José/Petén, Guatemala; ${ }^{6}$ Department of Botany, Museum of Natural History, Burgring 7, A-1010 Vienna; ${ }^{7}$ Department of Medicine I, Division: Institute of Cancer Research, Comprehensive Cancer Center, Medical University Vienna, Borschkegasse 8a; ${ }^{8}$ Institute of Medical Genetics, Medical University of Vienna, Währinger Strasse 10, A-1090 Vienna, Austria
\end{abstract}

Received August 6, 2012; Accepted October 1, 2012

DOI: 10.3892/ijo.2012.1690

\begin{abstract}
The present study investigates extracts of Neuolaena lobata, an anti-protozoan ethnomedicinal plant of the Maya, regarding its anti-neoplastic properties. Firstly, extracts of increasing polarity were tested in HL-60 cells analyzing inhibition of cell proliferation and apoptosis induction. Secondly, the most active extract was further tested in anaplastic large cell lymphoma (ALCL) cell lines of human and mouse origin. The dichloromethane extract inhibited proliferation of HL-60, human and mouse ALCL cells with an $\mathrm{IC}_{50}$ of $2.5,3.7$ and $2.4 \mu \mathrm{g} / \mathrm{ml}$, respectively and arrested cells in the $\mathrm{G} 2 / \mathrm{M}$ phase. The extract induced the checkpoint kinases Chk1 and Chk2 and perturbed the orchestrated expression of the Cdc 25 family of cell cycle phosphatases which was paralleled by the activation of $\mathrm{p} 53$, p21 and downregulation of c-Myc. Importantly, the expression of NPM/ALK and its effector JunB were drastically decreased, which correlated with the activation of caspase 3 . Subsequently also platelet derived growth factor receptor $\beta$ was downregulated, which was recently shown to be transcriptionally controlled by JunB synergizing with ALK in ALCL development. We show that a traditional healing plant extract downregulates various oncogenes, induces tumor suppressors, inhibits cell proliferation
\end{abstract}

Correspondence to: Professor Georg Krupitza, Institute of Clinical Pathology, Medical University of Vienna, Waehringer Guertel 18-20, A-1090 Vienna, Austria

E-mail: georg.krupitza@meduniwien.ac.at

Key words: Neurolaena lobata, NPM/ALK, JunB, PDGF-R, anaplastic large cell lymphoma, ethno-pharmacology and triggers apoptosis of malignant cells. The discovery of the 'Active Principle(s)' is warranted.

\section{Introduction}

Natural products comprise a vast diversity of complex structures and new chemical entities, whereas synthetic libraries typically show considerably less diversity (1). Similarly to vincristine, more than $60 \%$ of currently applied anticancer drugs are derived from natural sources, i.e., plants, microorganisms and marine organisms (2). Vincristine is an alkaloid in the leaves of the Madagaskar rosy periwinkle C.roseus, a plant that was traditionally used to treat conditions like hemorrhage, toothache, wounds, hyperglycemia and diabetic ulcers (3). In less-developed countries, a majority of the population still relies on traditional healing plants in treating various conditions. Traditional healing plants have the advantage that they have been successfully tested over the centuries, exhibit specificity and are therefore tolerable with little side effects. This makes them a prime source for the study of new therapeutic perspectives. Therefore, natural products from high biodiversity areas such as the lowland rain forests of El Peten, Guatemala, are in this respect of particular interest. In the present work, the Maya ethno-pharmacological plant Neurolaena lobata was selected for investigations based on its long history as anti-protozoan medicine (4). N. lobata is still widely used in Guatemala and Belize to cure a variety of diseases, particularly malaria and amoebiasis, fungus, ringworm and intestinal parasites (5). More recently it is used also as oncolytic home remedy. Hypoglycemic activity of the ethanol extract was demonstrated in vivo (6) and a recent study reported an inhibitory effect of $N$. lobata extracts on the transfer of HIV from dendritic cells to lymphocytes in vitro (7). A few characteristic sesquiterpene lactones which 
were isolated of $N$. lobata (8) exhibit cytotoxic effects in GLC4 and COLO 320 tumor cell lines (9), but show only weak toxicity on brine shrimp larvae Artemia salina (10).

Anaplastic large cell lymphoma (ALCL) represents appoximately $10-15 \%$ of childhood lymphoma, whereby the majority of them carry chromosomal aberrations involving the anaplastic lymphoma kinase (ALK) of which the $\mathrm{t}(2 ; 5)(\mathrm{p} 23 ; \mathrm{q} 35)$ translocation, which fuses the $A L K$ gene to the nucleophosmin (NPM) gene (11), represents the most frequent one (12). The resulting NPM/ALK fusion protein with constitutive tyrosine kinase activity is considered to play an essential role in the pathogenesis of ALCL through its impact on proliferation, differentiation and apoptosis (13) and malignant transformation in co-operation with other oncogenes (14). Therefore, ALK is suggested as target for therapeutic intervention. Most $\mathrm{ALK}^{+} \mathrm{ALCL}$ patients respond with complete remission upon first-line treatment. However, high relapse rates as well as long-term effects of chemotherapy and radiation therapy have to be considered, particularly in pediatric and adolescent patients, as both treatments potentially damage normal cells which might turn into secondary malignancies within decades of life time (15-17). Combinatorial chemotherapy (CHOP: cyclophoshamide, hydroxydaunorubicin (doxorubicin), oncovin (vincristine), prednisone) is applied in the first treatment approach of ALCL patients, sometimes combined with radiotherapy. Ongoing research tries to discover a treatment directly targeting ALK (18) and an ALK inhibitor, critozinib, is currently tested in a phase III trial (19). Here, we describe the property of the dichloromethane extract of the ethno-pharmacological plant N. lobata, which inhibits NPM/ ALK expression and its downstream effectors and its apoptosis inducing effects on leukemia and lymphoma cells at low concentrations.

\section{Materials and methods}

Plant material. Neurolaena lobata was collected in Guatemala, Departamento Petén, near the north-western shore of Lago Petén Itzá, $0.5 \mathrm{~km} \mathrm{NNW}$ of San José in the area of the Chakmamantokrock formation (16 59'16" N, 89 53'45" W). Voucher specimens (leg. R.O. Frisch, det. R.O. Frisch Nr. 7-2009 28. 04. 2009 , Herbarium W) were archived at the Museum of Natural History, Vienna, Austria. The fresh plant material (the aerial plant parts, leaves, caulis and florescence) of $N$. lobata was stored deepfrozen until lyophilization and subsequent extraction.

Plant extraction. Lyophilized aerial plant parts (leaves, florescence and stipes) of $N$. lobata were powdered and consecutively extracted with petroleum ether (PE), dichloromethane $\left(\mathrm{CH}_{2} \mathrm{Cl}_{2}\right)$, ethyl acetate $(\mathrm{EA})$, methanol $(\mathrm{MeOH})$ and water $\left(\mathrm{H}_{2} \mathrm{O}\right)$, leading to five extracts of distinct polarity. For this, plant powder was mixed at a concentration of 1:10 (w/v) with solvent and treated in an ultra sonic bath for $10 \mathrm{~min}$ to break the plant cells. The extraction was performed under reflux on a waterbath for $1 \mathrm{~h}$. Afterwards the content of the flask was filtered. The solid plant residue was air-dried overnight and reused for the following extraction step with the next, more polar solvent, whereas the dissolved material of the liquid phase was dried by rotary evaporation. Dried extracts were stored in a vacuum desiccator protected from light at $4^{\circ} \mathrm{C}$. Extract weights obtained from serial extraction of $20.0 \mathrm{~g}$ lyophilized plant material with five solvents of different polarity are shown in Table I. For further use in cell culture experiments only small amounts of the gained extracts were dissolved in DMSO. To account for detrimental effects of DMSO on cell proliferation, apoptosis and cell cycle, controls were treated with the respective concentrations of DMSO used for sample treatment. Maximum concentration of DMSO was limited to $0.5 \%$ to avoid cell damage due to toxicity of DMSO.

Cell culture. HL-60, human promyelocytic leukemia cells, were purchased from ATCC (American Type Culture Collection). HL-60, SR-786, NPM-ALK positive human ALCL (anaplastic large cell lymphoma) cells, and CD4-417, NPM-ALK positive mouse ALCL cells were grown in RPMI-1640 medium supplemented with $10 \%$ heat inactivated fetal calf serum (FCS), $1 \%$ L-glutamine and $1 \%$ penicillin/streptomycin. Primary human lung fibroblasts (HLFs), were cultivated in DMEM medium supplemented with $10 \%$ FCS and $1 \%$ penicillin/streptomycin. Media and supplements were purchased from Life Technologies. All cells were maintained in a humidified atmosphere containing $5 \% \mathrm{CO}_{2}$ at $37^{\circ} \mathrm{C}$.

Proliferation assay. HL-60 cells were treated with the plant extracts to discover the most anti-proliferative ones. For this, HL-60 cells were seeded in 24-well plates at a concentration of $1 \times 10^{5}$ cells $/ \mathrm{ml}$ allowing logarithmic growth within $72 \mathrm{~h}$. Afterwards cells were incubated with increasing concentrations of plant extracts. The cell number was determined twice within 24 h using a KX-21 N microcell counter (Sysmex Corp., Kobe, Japan). Proliferation rates were calculated as described $(20,21)$. Only the dichloromethane extract, which exhibited the strongest anti-neoplastic activity, was tested in other cell systems including SR-786, CD4-417 and HLF. ALCL SR-786 (human) and CD-417 (mouse) cell lines were counted using an electronic cell counter (Casy Roche). SR-786 cells were seeded in a 48-well plate at a concentration of $2 \times 10^{5}$ cells $/ \mathrm{ml}$. Then, the cells were incubated with increasing extract concentrations for $48 \mathrm{~h}$. CD4-417 cells were seeded in 48-well plates at a concentration of $1 \times 10^{6}$ cells $/ \mathrm{ml}$ and incubated with extract for $72 \mathrm{~h}$.

Alamar-blue cytotoxicity assay. The alamar-blue assay (Invitrogen, Life Technologies) was applied to measure cytotoxicity. The active component of alamar-blue is resazurin, which is a non-toxic and cell permeable compound. Upon entering an active cell resazurin is converted to bright red fluorescent resorufin via reduction reactions of cell metabolism. The amount of fluorescence produced is proportional to the number of living cells and corresponds to the cells metabolic activity. HLF cells were seeded into $500 \mu \mathrm{l}$ medium of a 48 -well plate at a concentration providing confluence within the wells after 48 h. CD4-417 cells were seeded into 48-well plates at a concentration of $1 \times 10^{6}$ cells $/ \mathrm{ml}$. Each well was filled with $500 \mu \mathrm{l}$ cell suspension. Increasing concentrations of dichloromethane extract or solvent were added and after 24 and $48 \mathrm{~h}$, respectively, $50 \mu \mathrm{l}$ alamar-blue reagent was added to each well and incubated for $\sim 90 \mathrm{~min}$ at $37^{\circ} \mathrm{C}$ until colour changed from blue to red. Afterwards the 48 -well plate was placed into a multi-detection reader for fluorescence and absorbance (Bio-Tek Instrument, Inc., Vermont, USA). Plate reader software KC-4 (Bio-Tek) was used to determine absorption at $570 \mathrm{~nm}$. To calculate the differences in cell viability, mean blank value (only medium) was subtracted 
Table I. N. lobata extract weights used for HL-60 treatment.

\begin{tabular}{lcc}
\hline Extract type & Used extract & Corresponding \\
concentrations & dried plant \\
$(\mu \mathrm{g} / \mathrm{ml}$ medium $)$ & weight $(\mu \mathrm{g})$
\end{tabular}

$\begin{array}{lrr}\text { Petroleum ether } & 5 & 113.1 \\ & 15 & 339.2 \\ & 30 & 678.3 \\ \text { Dichloromethane } & 60 & 1356.7 \\ & 5 & 168.9 \\ & 15 & 506.8 \\ \text { Ethyl acetate } & 30 & 1013.7 \\ & 60 & 2027.3 \\ & 5 & 341.4 \\ & 15 & 1024.2 \\ \text { Methanol } & 30 & 2048.4 \\ & 60 & 4096.8 \\ & 5 & 92.4 \\ \text { Water } & 15 & 277.3 \\ & 30 & 554.6 \\ & 60 & 1109.2 \\ & 5 & 41.6 \\ & 15 & 124.8 \\ & 30 & 249.5 \\ & 60 & 499.0\end{array}$

from all other measurement values to take fluorescence of the medium into account. Mean value of the control samples was considered as $100 \%$ cell viability. The mean values of treated samples are described as percentage of control sample viability.

Apoptosis assay. Hoechst 33258 (HO) and propidium iodide (PI) double staining (both Sigma, St. Louis, MO) allows the determination of the type of death the cell is undergoing, i.e., apoptosis (early or late) or necrosis (22-24). HL-60 cells were seeded in a 24-well plate at a concentration of $1 \times 10^{5}$ cells $/ \mathrm{ml}$ and treated with increasing concentrations of the specified extracts. After $24 \mathrm{~h}$ of incubation, $100 \mu \mathrm{l}$ cell suspension of each well were transferred into separate wells of a 96-well plate and Hoechst 33285 and propidium iodide were added at final concentrations of 5 and $2 \mu \mathrm{g} / \mathrm{ml}$, respectively. After $1 \mathrm{~h}$ of incubation at $37^{\circ} \mathrm{C}$, stained cells were examined and photographed on a fluorescence microscope (Axiovert, Zeiss) equipped with a DAPI filter. Type and number of cell deaths was evaluated by visual examination of the images according to the morphological characteristics revealed by HOPI staining.

Cell cycle distribution (FACS) analysis. CD-417 cells were seeded in a 6-well plate at a concentration of $1 \times 10^{6}$ cells $/ \mathrm{ml}$. Then dichloromethane extract of $N$. lobata was added to a final concentration of 5,10 and $15 \mu \mathrm{g} / \mathrm{ml}$. After $24 \mathrm{~h}$ of incubation at $37^{\circ} \mathrm{C}$, cells were harvested, transferred into $15-\mathrm{ml}$ tubes and centrifuged $\left(4^{\circ} \mathrm{C}, 800 \mathrm{rpm}, 5 \mathrm{~min}\right)$. The supernatant was discarded and the cell pellet was washed with cold PBS, centrifuged $\left(4^{\circ} \mathrm{C}, 800 \mathrm{rpm}, 5 \mathrm{~min}\right)$, resuspended in $1 \mathrm{ml}$ cold ethanol $\left(70 \%\right.$ ), and either fixed for $30 \mathrm{~min}$ at $4^{\circ} \mathrm{C}$ or stored at $-20^{\circ} \mathrm{C}$ prior further handling. After two washing steps with cold PBS, the cell pellet was resuspended in $500 \mu \mathrm{l}$ cold PBS and transferred into a $5 \mathrm{ml}$ polystyrene round bottom tube. RNAse $\mathrm{A}$ and propidium iodide were added to a final concentration of $50 \mu \mathrm{g} / \mathrm{ml}$ each and incubated for $1 \mathrm{~h}$ at $4^{\circ} \mathrm{C}$. The final cell number was adjusted between 0.5 and $1 \times 10^{6}$ cells in $500 \mu$ l. Cells were analyzed by FACSCalibur flow cytometer (BD Bioscience, San Jose, CA, USA). Cell cycle distribution was calculated with ModFid LT software (Verity Software House, Topsham, ME, USA).

Western blotting. CD4-417 cells were seeded in a 6-well plate at a concentration of $10^{6}$ cells $/ \mathrm{ml}$ and treated with $10 \mu \mathrm{g} / \mathrm{ml}$ of the dichloromethane extract of $N$. lobata. SR-786 cells were seeded in a T-75 tissue culture flask at a concentration of $2.5 \times 10^{5}$ cells/ $\mathrm{ml}$ and incubated with $15 \mu \mathrm{g} / \mathrm{ml}$ dichloromethane extract. Cells $\left(10^{6}\right)$ were harvested after 4,8 and $24 \mathrm{~h}$. Additionally, Proteasome Inhibitor IV (cat. no. 539175, Merck) was added to a final concentration of $50 \mu \mathrm{M}$ in a single experiment. In another experiment lysosome inhibitor ammonium chloride $\left(\mathrm{NH}_{4} \mathrm{Cl}\right)$ was added at a concentration of $20 \mathrm{mM}$. HL-60 cells were seeded in T-75 tissue culture flasks at a concentration of $1.8 \times 10^{5}$ cells/ $\mathrm{ml}$ and incubated with $15 \mu \mathrm{g} / \mathrm{ml}$ extract. HLFs were grown in a 6-well plate and incubated with 10 and $15 \mu \mathrm{g} / \mathrm{ml}$ dichloromethane extract of $N$. lobata. Cells were washed twice with cold PBS and centrifuged at $1000 \mathrm{rpm}$ for $5 \mathrm{~min}$ at $4^{\circ} \mathrm{C}$. The cell pellet was lysed in a buffer containing $150 \mathrm{mM} \mathrm{NaCl}, 50 \mathrm{mM}$ Tris $\mathrm{pH}$ 8.0, $1 \%$ Triton-X-100, $1 \mathrm{mM}$ phenylmethylsulfonyl fluoride (PMSF) and $1 \mathrm{mM}$ Protease Inhibitor Cocktail (PIC), (Sigma, Schnelldorf, Germany). The lysate was centrifuged at $12000 \mathrm{rpm}$ for $20 \mathrm{~min}$ at $4^{\circ} \mathrm{C}$. Supernatant was transferred into a $1.5-\mathrm{ml}$ tube and stored at $-20^{\circ} \mathrm{C}$ until further analysis. Equal amounts of protein lysate were mixed with SDS (sodium dodecyl sulphate) sample buffer and loaded onto a $10 \%$ polyacrylamide gel. Proteins were separated by polyacrylamide gel electrophoresis (PAGE) at $120 \mathrm{~V}$ and electro-transferred onto a PVDF (polyvinylidene difluoride) membrane (Hybond, Amersham, Buckinghamshire, UK) at $95 \mathrm{~V}$ for $80 \mathrm{~min}$. Membranes were allowed to dry for $\geq 30$ min up to $2 \mathrm{~h}$ to provide fixing of the proteins to the membrane. Methanol was used to remoisten the membranes. Equal sample loading was checked by staining the membrane with Ponceau S (Sigma). After removing Ponceau $S$ with PBS or TBS (Tris-buffered saline, pH 7.6), membranes were blocked in PBS- or TBS-milk (5\% non-fat dry milk in PBS containing $0.5 \%$ Tween- 20 or TBS containing $0.1 \%$ Tween-20) for $1 \mathrm{~h}$. Then, membranes were washed with PBS/T (PBS containing $0.5 \%$ Tween-20) or TBS/T (TBS containing $0.1 \%$ Tween-20), changing the washing solution 4-5 times, for $\geq 20 \mathrm{~min}$. Next, membranes were incubated with the primary antibody in blocking solution (according to the data sheet TBS-, PBS-milk or TBS-, PBS-BSA) diluted 1:500-1:1000, gently shaking at $4^{\circ} \mathrm{C}$, overnight. Thereafter, membranes were washed again with PBS/T or TBS/T and incubated with the secondary antibody (peroxidase conjugated anti-rabbit IgG or anti-mouse $\mathrm{IgG}$ ) diluted 1:2000 in PBS- or TBS-milk at room temperature for $1 \mathrm{~h}$. Chemiluminescence was developed by ECL detection kit (Amersham) and membranes were exposed to Amersham Hyperfilm. 
A

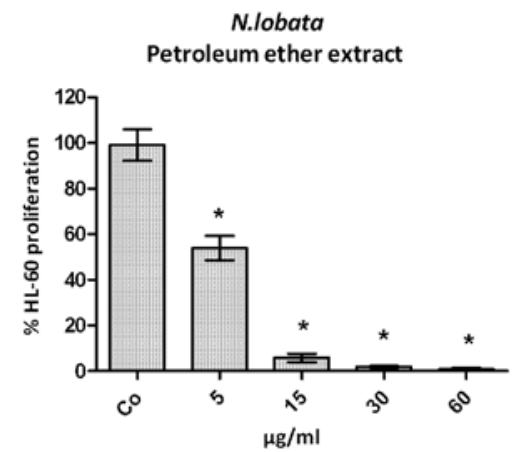

N.lobata Ethyl acetate extract

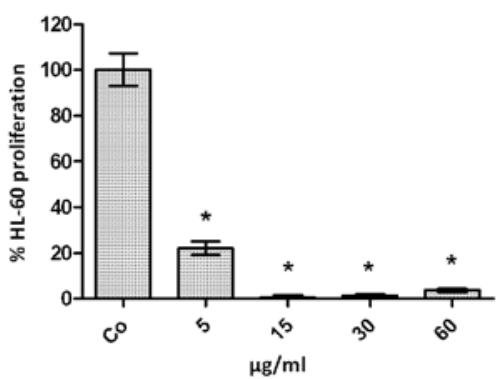

N.lobata

Water extract

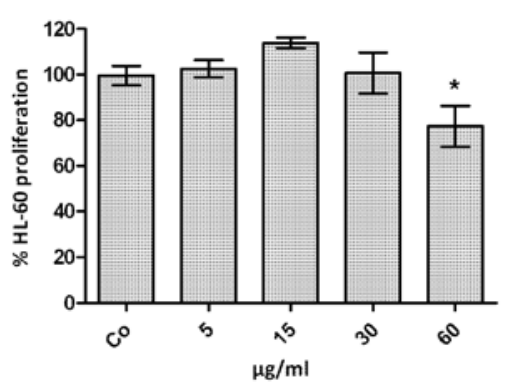

B

N.lobata Petroleum ether extract

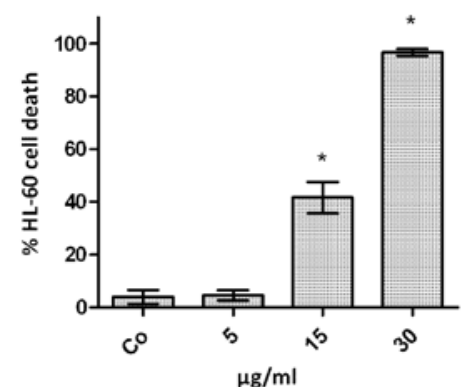

N.lobata

Ethyl acetate extract

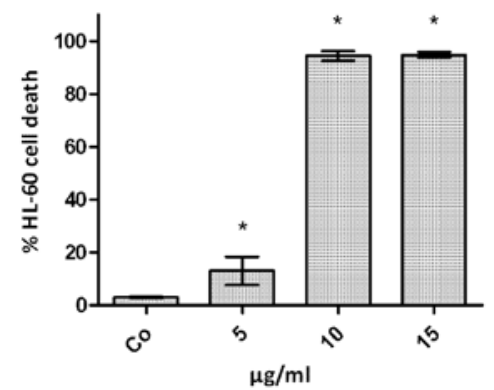

N.lobata

Dichloromethane extract

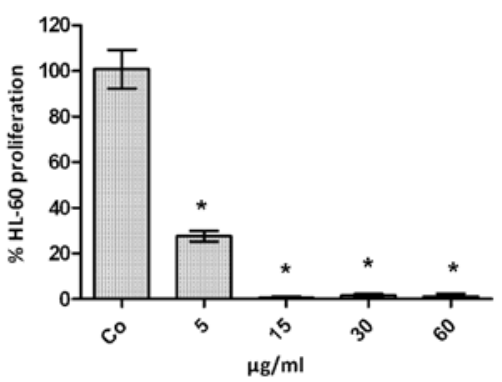

N.lobata

Methanol extract

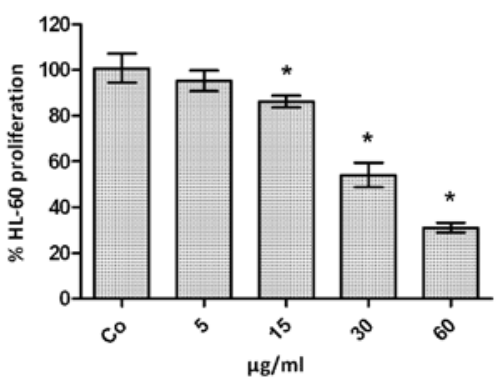

Figure 1. Effects of different extracts of N. lobata on (A) proliferation and (B) apoptosis of HL-60 cells. Logarithmically growing cells were seeded at a concentration of $10^{5}$ cells $/ \mathrm{ml}$, and treated with the indicated extract concentrations [(A) petroleum ether, dichloromethane, ethyl acetate, methanol, water]. Cells were counted twice within $24 \mathrm{~h}$ and the proliferation rate was calculated relative to solvent treated controls. (B) Cells were stained with Hoechst 33258 and propidium iodide to detect apoptotic cells using a fluorescence microscope equipped with a DAPI filter. Experiments were performed in triplicate. Error bars indicate \pm SD. Asterisks indicate significant alterations in number of apoptotic cells compared to control $(\mathrm{p}<0.05)$.

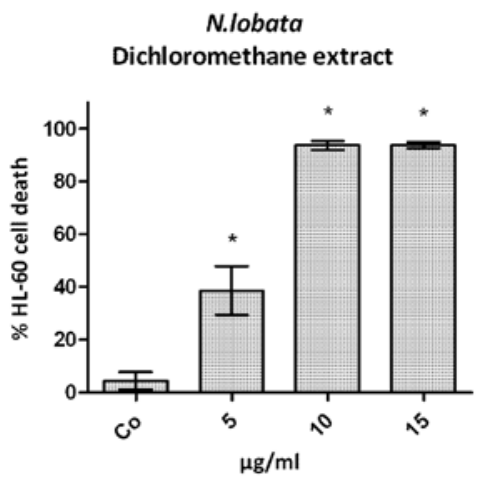

N.lobata

Methanol extract

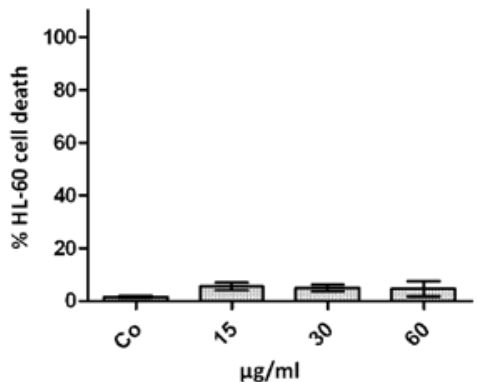


The used antibodies were: CD246, ALK protein, monoclonal mouse, clone ALK1, code M7195 and Nucleophosmin, monoclonal mouse, clone 376, code M7305 (DakoCytomation); PDGF Receptor $\beta$ (28E1) Rabbit mAB, no. 3169; Chk1 (2G1D5) Mouse mAb, no. 2360; Phospho-Chk1 (Ser345) Antibody, no. 2341; Chk2 Antibody, no. 2662; Phospho-Chk2 (Thr68) Antibody, no. 2661; Cleaved PARP (Asp214) Antibody (Mouse Specific), no. 9544; Cleaved Caspase 3 (Asp175) Antibody, no. 9661; Caspase 3 Antibody, no. 9662; Phospho-cdc2 (Tyr15)(10A11) Rabbit mAb, no. 4539; Phospho-p53 (Ser20) Antibody, no. 9287; Phospho-Akt (Ser473)(587F11) Mouse mAb, no. 4051; Akt Antibody, no. 9272, all from (Cell Signaling); PhosphoDetect Anti-H2AX (pSer139), DR 1017 (EMD4Biosciences); p53, mouse monoclonal, cat. no. 1767 (Immunotech, Coulter Co.); PARP-1 (F-2): sc-8007, mouse monoclonal; Cdc25A (F-6): sc-7389, mouse monoclonal; Cdc25B (C-20): sc-326, rabbit polyclonal; Cdc25C (C-20): sc-327, rabbit polyclonal; Cdc2 p34 (17): sc-54, mouse monoclonal; JunB (120): sc-73, rabbit polyclonal; c-Jun (H-79): sc-1694, rabbit polyclonal; p21 (C-19): sc-397, rabbit polyclonal, all from (Santa Cruz Biotechnology, Inc.); c-Myc Ab-2 (9E10.3), no. MS-139-P1, mouse monoclonal (Thermo Fisher Scientific, Inc.); $\beta$-actin, monoclonal mouse ascites fluid, clone AC-15, cat. no. A5441 (Sigma).

Quantitative RT-PCR. SR-786 cells were seeded in T-75 tissue culture flasks at a concentration of $2.5 \times 10^{5}$ cells $/ \mathrm{ml}$ and incubated with $15 \mu \mathrm{g} / \mathrm{ml}$ dichloromethane extract of N. lobata. After 4 and $8 \mathrm{~h}$ cells were harvested and homogenized using Qia-shredder (Qiagen) and RNA isolated according to the instructions of RNeasy Mini Kit (Qiagen). RNA concentration was measured using a NanoDrop Fluorospectrometer (Thermo Fisher Scientific, Inc.) and RNA was stored at $-80^{\circ} \mathrm{C}$ until further processing. First-strand cDNA synthesis from $1 \mu \mathrm{g}$ RNA was performed using Superscript first-strand synthesis systems for RT-PCR (Invitrogen). cDNA synthesis reaction was primed using random hexamers. Desired mRNA was obtained by choosing specific primers in the PCR. NPM/ALK transcript levels in SR-786 cells were investigated by RT-PCR using TaqMan detection system. The housekeeping gene glyceralaldehyde 3-phosphate dehydrogenase (GAPDH) served as reference gene. For each sample, $7 \mu 1 \mathrm{H}_{2} \mathrm{O}, 10 \mu \mathrm{l}$ TaqMan universal PCR master mix (Applied Biosystems), $1 \mu \mathrm{l}$ primer and probe and $2 \mu \mathrm{l}$ cDNA, or $2 \mu 1 \mathrm{H}_{2} \mathrm{O}$ for negative controls, were filled into a well of a 96-well optical reaction plate. In case of GAPDH amplification, the primer and probe mixture from TaqMan gene expression kit (Applied Biosystems) was used. To detect NPM/ALK transcripts, forward primer (GTG GTC TTA AGG TTG AAG TGT GGT T) and reverse primer (GCT TCC GGC GGT ACA CTA CTA A) were mixed with the probe (TGC TGT CCA CTA ATA TGC ACT GGC CCT) prior adding to the reaction mix. Final concentration of primers and probe in the sample mixtures were 0.5 and $0.25 \mu \mathrm{M}$, respectively. Cycle program $\left(95^{\circ} \mathrm{C}\right.$ for $10 \mathrm{~min}$ to activate polymerase followed by 40 cycles of $95^{\circ} \mathrm{C}$ for $15 \mathrm{sec}$ and $60^{\circ} \mathrm{C}$ for $1 \mathrm{~min}$ ) was started on an ABI PRISM 7000 Sequence Detection System (Applied Biosystems). RT-PCR was performed in duplicates for each cDNA template and gene investigated. Negative controls, containing water instead of cDNA, confirmed the absence of RNA/DNA in all reagents applied in the assay. Comparative $\mathrm{C}_{\mathrm{T}}\left(\Delta \Delta \mathrm{C}_{\mathrm{T}}\right)$ method (25) was used to quantify NPM/ALK expression relative to GAPDH expression using the formula below. The $\mathrm{C}_{\mathrm{T}}$ value is determined as the number of PCR cycles that is needed to reach a defined level of fluorescence and therefore newly synthesized DNA. Ratio $=2-{ }^{\Delta \Delta C T} . \Delta \mathrm{C}_{\mathrm{T}}$ $=\mathrm{C}_{\mathrm{T}}$ target gene $(\mathrm{NPM}-\mathrm{ALK})-\mathrm{C}_{\mathrm{T}}$ control gene $(\mathrm{GAPDH})$. $\Delta \Delta \mathrm{C}_{\mathrm{T}}=\Delta \mathrm{C}_{\mathrm{T}}$ drug treatment $-\Delta \mathrm{C}_{\mathrm{T}}$ control sample.

Statistical analysis. The apoptosis, proliferation, toxicity, FACS and Q-PCR experiments were analyzed by t-test using GraphPad Prism version 4 (GraphPad Prim Sofware, Inc., San Diego, CA, USA). Data were considered statistically significant at $\mathrm{p} \leq 0.05$.

\section{Results}

Anti-neoplastic activities of $N$. lobata extracts in HL-60 cells. To explore anti-neoplastic effects logarithmically growing HL-60 cells were treated with increasing extract concentrations $(5-60 \mu \mathrm{g} / \mathrm{ml})$ of the aerial parts of N. lobata and the effects on cell proliferation and apoptosis were monitored. All extracts dose-dependently inhibited proliferation whereby the dichloromethane and ethyl acetate extract exhibited the highest and the methanol and water extract the lowest activities (Fig. 1A). Therefore, the water extract was excluded from further analyses. From the remaining four extracts the dichloromethane extract induced the strongest pro-apoptotic effect (Fig. 1B) and subsequent investigations were hence continued with this extract type.

The dichloromethane extract inhibits proliferation of human and murine ALCL cells. We decided to test the N. lobata dichloromethane extract (further on simply called 'extract') in ALCL cells, because there is still no specific cure available for this malignancy. Human ALCL SR-786 and murine ALCL CD4-417 cells were treated with increasing concentrations of extract to analyze the inhibition of cell proliferation. The concentration inhibiting $50 \%$ of the proliferation of SR-786 cells was $\sim 3.8 \mu \mathrm{g} /$ $\mathrm{ml}$ and of CD4-417 cells $\sim 2.5 \mu \mathrm{g} / \mathrm{ml}$ (Fig. 2A). In both cell lines the extract inhibited the cell cycle dose-dependently in the G2/M phase, which resulted in an accumulation of the cells in this cycle phase paralleled by a decreasing number of cells particularly in S-phase (Fig. 2B). The anti-proliferative effect of the extract was specific for the tested leukemia and lymphoma cell lines, because there was no significant toxicity observed in normal human lung fibroblasts (HLF) compared to CD4-417 cells (Fig. 2C).

$N$. lobata extract activates DNA damage checkpoints. In both ALCL cell lines the extract induced the phosphorylation (activation) of Chk1 and in human SR-786 cells also Chk2 activation was evident (Fig. 3A). This was consistent with the downregulation of $\mathrm{Cdc} 25 \mathrm{C}$, the concomitant increase of the inhibitory Cdk1 phosphorylation and with cell cycle arrest in G2/M. In contrast, the expression of $\mathrm{Cdc} 25 \mathrm{~B}$ was upregulated and Cdc25A unaffected in SR-786 cells. In murine CD4-417 cells Cdc25A became downregulated after $24 \mathrm{~h}$ (Fig. 3B). Conflicting signaling of $\mathrm{Cdc} 25$ family proteins is an alternative explanation for the observed G2/M cell cycle arrest.

N. lobata extract induces tumor suppressors and inhibits oncogenes. The induction of DNA checkpoints was paralleled by the activation of p53 indicated by its phosphorylation at serine 20 and concomitant increase of its direct transcriptional target p21. 
$\mathbf{A}$
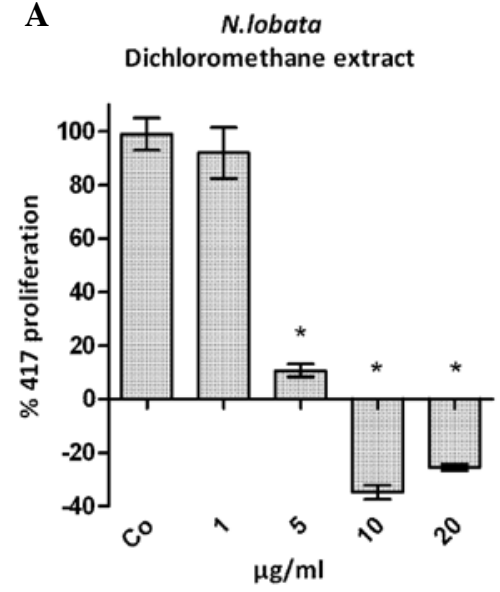

B Cell cycle distribution after $24 \mathrm{~h}$ dichloromethane extract treatment

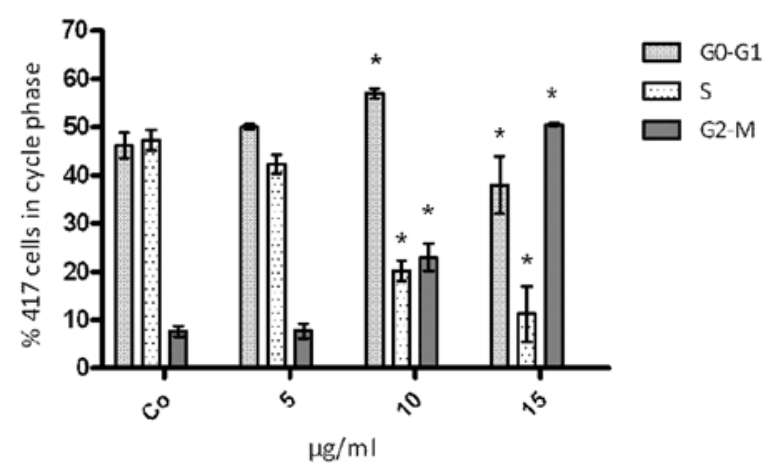

C

N.lobata

Dichloromethane extract

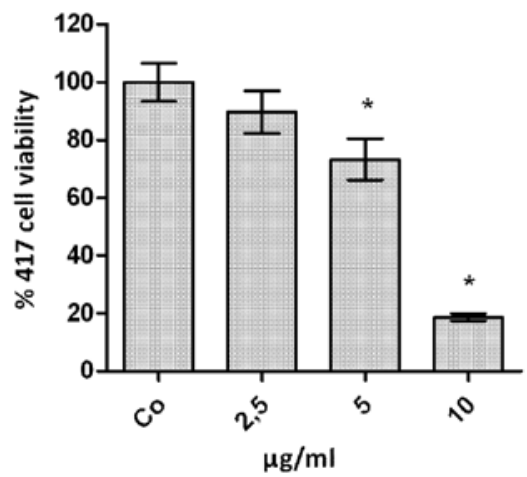

N.lobata

Dichloromethane extract

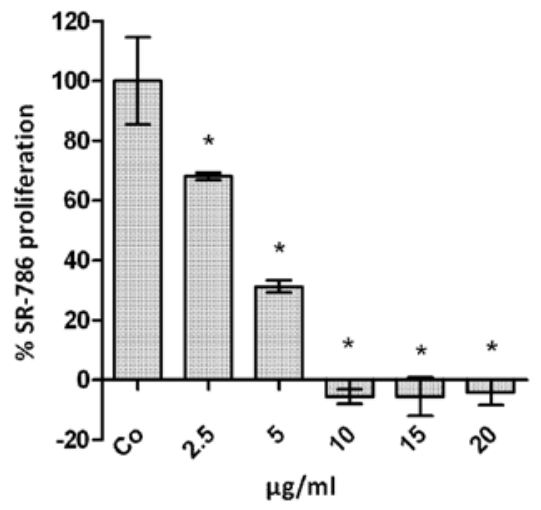

Cell cycle distribution after $24 \mathrm{~h}$ dichloromethane extract treatment

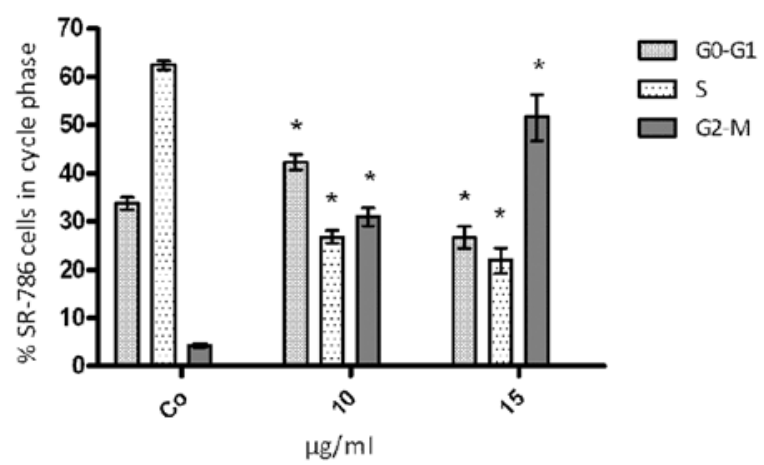

N.lobata

Dichloromethane extract

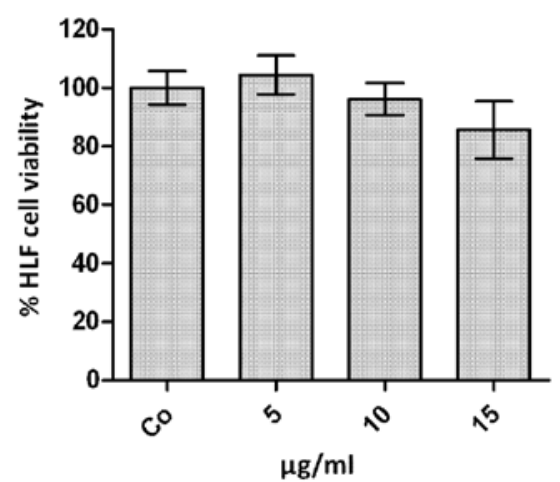

Figure 2. (A) Cell cycle inhibition by the dichloromethane extract of $N$. lobata. CD4-417 cells/ml (106) (left diagram) and 2x105 SR-786 cells/ml (right diagram) were seeded and incubated with the dichloromethane extract of $N$. lobata at the indicated concentrations. Cells were counted twice within 24 h of treatment using a Casy cell counter and the proliferation rate was calculated relative to solvent treated controls. (B) Cell cycle distribution upon treatment with the dichloromethane extract of $N$. lobata. CD4-417 cells $/ \mathrm{ml}\left(10^{6}\right)$ (left diagram) and $2 \times 10^{5}$ SR-786 cells $/ \mathrm{ml}$ (right diagram) were incubated with the indicated extract concentrations for $24 \mathrm{~h}$, harvested and subjected to FACS analysis. Experiments were performed in triplicate. Error bars indicate \pm SD. Asterisks indicate significant alterations compared to control ( $\mathrm{p}<0.05)$. (C) Alamar-blue cytotoxicity assay (left diagram) in cell line CD4-417 and (right diagram) normal primary human lung fibroblasts (HLFs) after $48 \mathrm{~h}$ of incubation with the dichloromethane extract of $N$. lobata at indicated concentrations. CD4-417 cells (left diagram) and HLFs (right diagram) were treated with the dichloromethane extract, $50 \mu 1$ alamar-blue reagent was added to each well and metabolically active cells were detected at 570 nm using a multi-well plate reader.

Also c-Myc was shown to negatively regulate the transcription of p21 (26) and hence, c-Myc downregulation may have caused p21 induction. It is of note that p21 upregulation (after $4 \mathrm{~h}$ ) precisely correlated with the downregulation of c-Myc in SR-786 cells. Also the expression of JunB was dramatically inhibited whereas c-Jun levels increased and an additional protein band with reduced electrophoretic mobility appeared on the western blotting indicating a post-translational modified c-Jun protein (Fig. 4). JunB and c-Jun are overexpressed in ALCL favoring progression (27). Taking together, the activation of $\mathrm{p} 53$, the induction of p21, and the inhibition of c-Myc and JunB expression certainly contributed to proliferation arrest. 
A

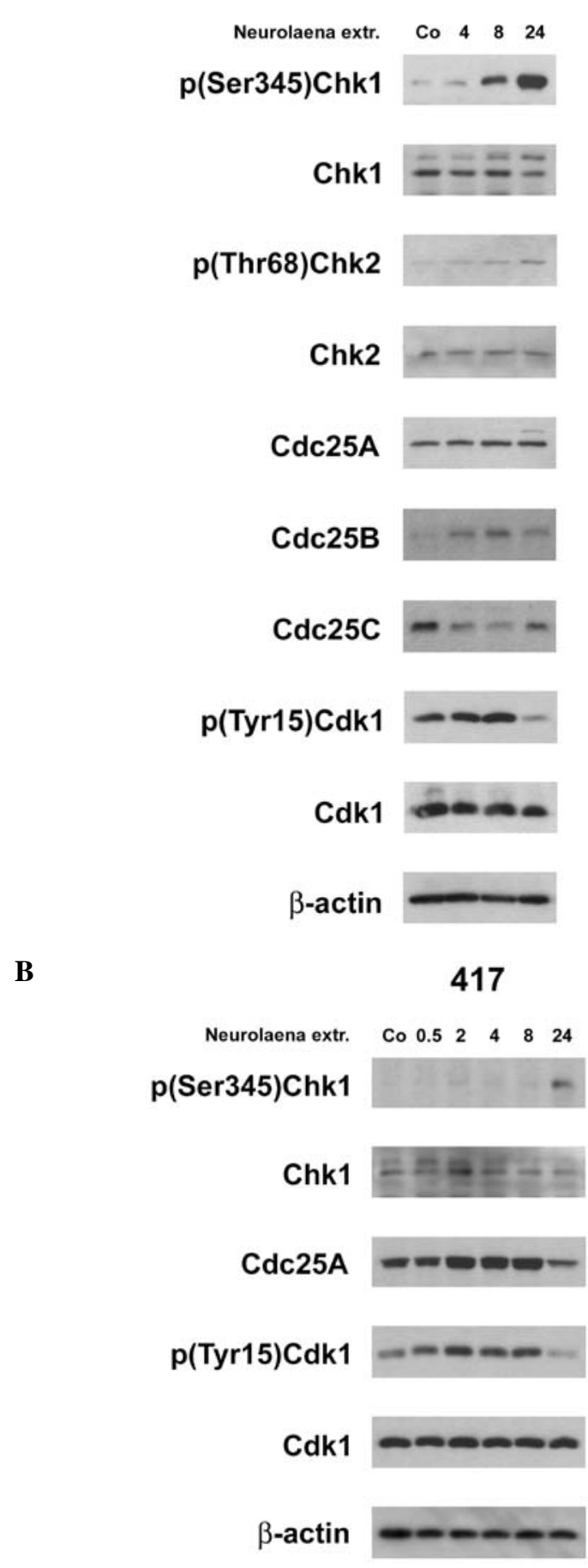

Figure 3. Alteration in the expression of cell cycle regulatory proteins. (A) SR-786 cells were treated with $15 \mu \mathrm{g} / \mathrm{ml}$ and (b) CD4-417 cells with $10 \mu \mathrm{g} / \mathrm{ml}$ dichloromethane extract for the indicated times, lysed and proteins subjected to western blot analysis using antibodies against the indicated proteins and phosphorylation sites. Equal sample loading was confirmed by Ponceau $\mathrm{S}$ staining and $\beta$-actin analysis.

N. lobata extract inhibits expression of NPM/ALK. As mentioned above, high JunB levels are common in ALCL (27) and caused by NPM/ALK (28). Hence, the decrease of JunB protein levels tempted us to analyze the effect of the extract on the expression of NPM/ALK. Treatment of SR-786 cells with the extract decreased the level of NPM/ALK with similar kinetics as JunB

\section{SR-786}

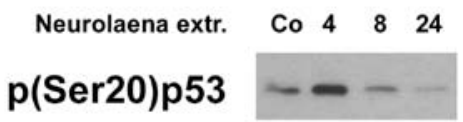

p53

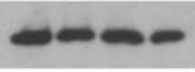

p21
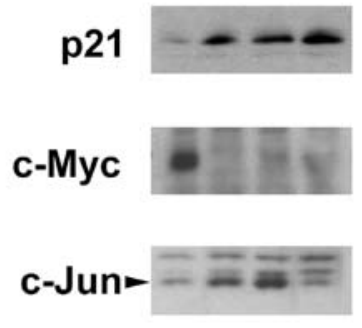

JunB

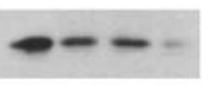

$\beta$-actin

Figure 4. Effects of the dichloromethane extract on oncogenes and tumor suppressors. SR-786 cells were incubated with $15 \mu \mathrm{g} / \mathrm{ml}$ dichloromethane extract of $N$. lobata and harvested after 4,8 and $24 \mathrm{~h}$ of treatment. Cells were lysed, protein samples subjected to electrophoretic separation and to western blot analysis with the indicated antibodies. Equal sample loading was confirmed by Ponceau $\mathrm{S}$ staining and $\beta$-actin analysis.

which is consistent with the role of NPM/ALK in the induction of JunB (Fig. 5A). Therefore, we challenged the specificity of the $N$. lobata extract and treated SR-786 cells with the petroleum ether extract of Critonia morifolia, which is another plant with strong anti-neoplastic properties (29). C. morifolia extract (20 $\mu \mathrm{g} / \mathrm{ml})$ exhibits a similar cytotoxic activity against HL-60 cells as $10 \mu \mathrm{g} / \mathrm{ml} \mathrm{N}$. lobata extract (data not shown). However, $20 \mu \mathrm{g} / \mathrm{ml}$ of $C$. morifolia extract had no effect on NPM/ALK expression in SR-786 cells (Fig. 5B). Therefore, we considered the effect of the N. lobata extract on NPM/ALK suppression as being specific. NPM/ALK was reported to permanently activate Akt via PI3K $(30,31)$. The western blot analysis of untreated control cells showed a low constitutive Akt serine 473 phosphorylation level, which further and transiently decreased upon treatment with $N$. lobata extract. The downregulation of NPM/ALK correlated also with the activation of caspase 3 and the occurrence of the signature type cleavage product of PARP and an increase of $\gamma \mathrm{H} 2 \mathrm{AX}$. In contrast, the expression of $\mathrm{NPM}$, the 5-prime fusion partner of the $\mathrm{t}(2 ; 5)(\mathrm{p} 23 ; \mathrm{q} 35)$ translocation was not inhibited. Next, we tested whether NPM/ALK downregulation was due to accelerated protein degradation. However, neither $20 \mathrm{mM}$ ammonium chloride, which inhibits the lysosomal pathway (32) nor $50 \mu \mathrm{M}$ Proteasome inhibitor IV reversed the reduction of NPM/ALK expression levels (Fig. 5C). Instead, the extract decreased the NPM/ALK transcript levels (Fig. 5D).

$N$. lobata extract inhibits expression of $P D G F-R \beta$. It was shown that NPM/ALK induces JunB and c-Jun $(27,28)$. Recently 


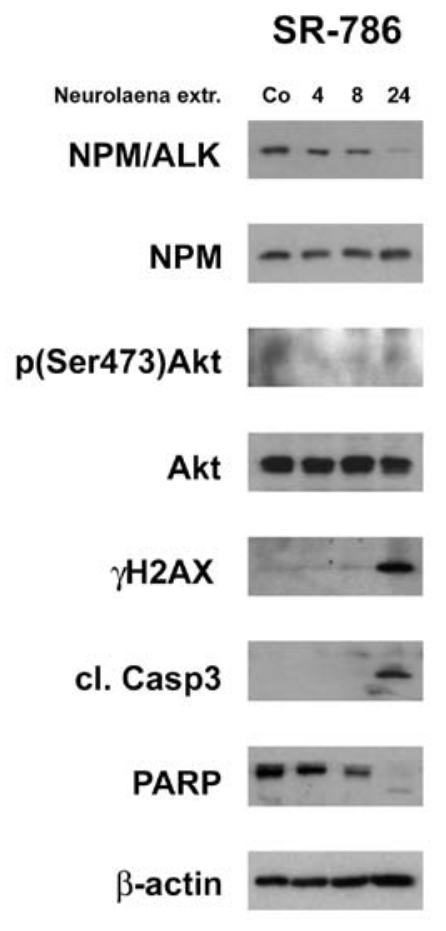

B

\section{SR-786}

Critonia extr.

Co $\quad 4 \quad 8 \quad 24$

NPM/ALK

NPM

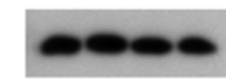

$\beta$-actin

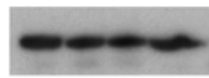

C

SR-786

Neurolaena extr.

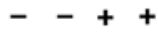

Lys. Inh.

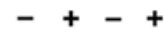

NPM/ALK

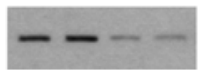

$\beta$-actin

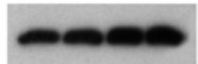

JunB and c-Jun were identified as transcriptional activators of PDGF-R $\beta$ which synergizes with ALK in ALCL development as confirmed in an ALCL mouse model. In human ALCL PDGF-R $\alpha$ takes this part. It was recently shown that imatinib and nilotinib are potent treatment options for ALCL because both inhibit PDGF-R (33). Interestingly, in established human ALCL cell lines harboring the $\mathrm{t}(2 ; 5)(\mathrm{p} 23 ; \mathrm{q} 35)$ translocation PDGF-R $\alpha$ expression disappears, whereas in murine ALCL cell lines PDGF-R $\beta$ remains expressed in certain cell lines (33). Therefore, we tested whether extract treatment affects the expression of PDGF-R $\beta$ in the murine CD4-417 ALCL cell line. The extract inhibited first the expression of NPM/ALK and its mediator JunB (4 h) and then the PDGF-R $\beta$ (8 h) (Fig. 6A). While it was shown that PDGF-R $\beta$ promotes tumor growth and progression $(34,35)$ we demonstrate that reduced NPM/ALK expression (after $4 \mathrm{~h}$ ) correlated with caspase 3 activation, signature type cleavage of PARP and occurrence of $\gamma \mathrm{H} 2 \mathrm{AX}$, rather than whith downregulation of PDGF-R $\beta$ expression (after $8 \mathrm{~h}$ ) (Fig. 6A). This was consistent with the observation that tyrosine kinase inhibition induced caspase-dependent apoptosis of $\mathrm{ALK}^{+} \mathrm{ALCL}$ (36). In normal HLFs PDGF-R $\beta$ was only slightly reduced after $24 \mathrm{~h}$ of extract treatment and caspase 3 was not activated (Fig. 6B) indicating specificity of the extract towards malignant cells.

We wanted to know whether an ALCL standard therapy, vincristine, also downregulates NPM/ALK and PDGF-R $\beta$. Although vincristine dose- and time-dependently inhibited PDGF-R $\beta$ protein expression it only marginally inhibited NPM/ ALK expression (Fig. 6C). Therefore, vincristine seems to exert its anti-ALCL activity through downregulation of PDGF-R $\beta$ and thus, targets the same protagonist as imatinib, yet by a different mechanism. In contrast, $N$. lobata extract targets mainly NPM/ ALK, which further interferes with signaling downstream to

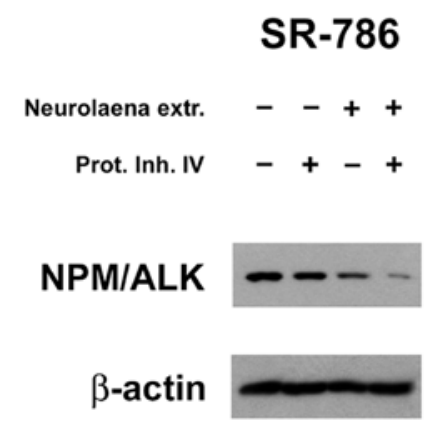

Figure 5. Expression of NPM/ALK and apoptosis regulators upon treatment with plant extracts. (A) SR-786 cells were incubated with $15 \mu \mathrm{g} / \mathrm{ml} \mathrm{N}$. lobata dichloromethane extract or (B) $20 \mu \mathrm{g} / \mathrm{ml}$ C. morifolia petroleum ether extract and harvested after the indicated times. (C) To analyse the contribution of protein degradation cells were co-treated with $20 \mathrm{mM}$ ammonium acteate (left panels) to inhibit lysosome activity or with $50 \mu \mathrm{M}$ proteasome inhibitor IV (right panels) and were harvested after $8 \mathrm{~h}$. Proteins of lysed cells were electrophoretically separated and subjected to western blot analysis using the indicated antibodies. NPM/ALK was detected by using antibody against ALK, which was not expressed in these cells. Equal sample loading was confirmed by Ponceau $S$ staining and $\beta$-actin analysis. (D) RNA was isolated, transcribed into cDNA and subjected to real-time-PCR using specific primers for NPM/ALK and GAPDH (as internal control). NPM/ALK expression was quantified using the comparative CT method. Experiments were performed in duplicates. Error bars indicate \pm SD. 


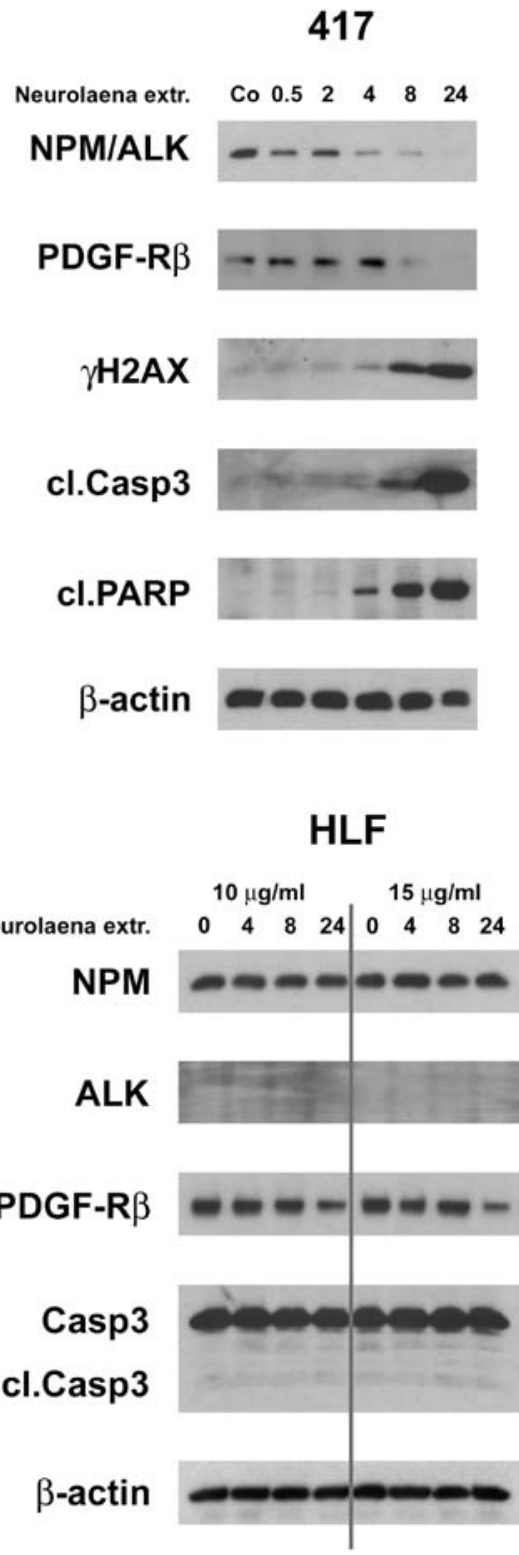

C

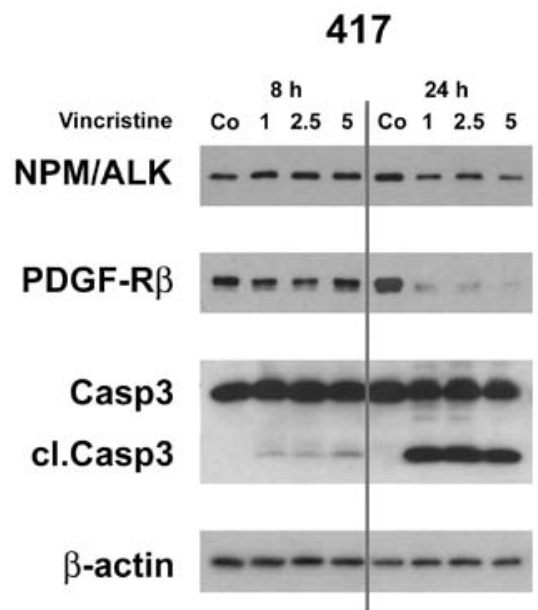

Figure 6. Effects of $N$. lobata dichloromethane extract on tyrosine kinases and apoptosis regulators. (A) CD-417 were treated with $10 \mu \mathrm{g} / \mathrm{ml}$ extract or (C) $1,2.5$ and $5 \mu \mathrm{M}$ vincristine and (B) primary HLFs with 10 and $15 \mu \mathrm{g} /$ $\mathrm{ml}$ extract and then cells were harvested at the indicated times, lysed and proteins subjected to electrophoretic separation and western blotting using antibodies against the indicated proteins. Equal sample loading was confirmed by Ponceau $\mathrm{S}$ staining and $\beta$-actin analysis.
JunB and to PDGF-R $\beta$. This points towards a specific 'active principle' which is contained in the extract and could be used to combat ALCL. Inhibition of ALK with critozinib and of PDGF-R with imatinib increased the survival rates in an ALCL mouse model dramatically (33). Therefore, it can be expected that the extract of $N$. lobata may have a strong effect in the repression of ALCL. Furthermore, the extract must contain also other anti-neoplastic components, because HL-60 cells, which neither harbor the $\mathrm{t}(2 ; 5)(\mathrm{p} 23 ; \mathrm{q} 35)$ translocation nor express $\mathrm{p} 53$ were killed by low extract concentrations.

\section{Discussion}

In search of novel cancer and lymphoma therapies we tested traditional healing plants and purified plant compounds regarding their anti-neoplastic properties (37-46). The rationale for plant selection was their ethno-pharmaceutical use against chronic inflammation or severe skin defects (4). In the present study we analysed $N$. lobata, a plant which is widely used in Maya folk medicine to treat malaria (4). A panel of characteristic sesquiterpene lactones were isolated of $N$. lobata such as neurolenin A- F and lobatin A-C (8) and also pyrrolizidine alkaloids (47). The plant extract and pure sesquiterpene lactones (i.e., neurolenin B), which were isolated from the dichloromethane extract, were most active against Plasmodium falciparum and P. berghei, whereas lobatin B was most cytotoxic in GLC4 and COLO320 tumor cell lines (9). This strongly suggests that the active principles of the dichloromethane extract used in our research were also sesquiterpene derivatives. Other drugs of this substance class, i.e., artemisinin, thapsigargin, and parthenolide, have already reached clinical trials. These compounds exhibit higher selectivity toward cancer cells then other commonly used chemotherapeutic drugs $(48,49)$. In recent years also Maya shamans of Guatemala treat cancer patients with $N$. lobata preparations. In the present study we demonstrate that the dichloromethane extract inhibits oncogenes such as c-Myc and JunB and induces the tumor suppressors p53 and p21. It blocks NPM/ALK expression at the transcriptional level and to the best of our knowledge this is the first description of a remedy with this specific property. It was shown that NPM/ALK activates PI3K and the survival promoting kinase Akt $(30,31)$. Here, the downregulation of NPM/ALK by the $N$. lobata extract correlated with the activation of caspase 3 and apoptosis. In addition, NPM/ALK induces the expression of the oncogene JunB (28) that is associated with NPM/ALK carcinogenic transformation (50). JunB overexpression is a hallmark of non-Hodgkin lymphomas such as ALCL (27) and drives the proliferation and progression of these malignancies. The kinetics of extract-mediated NPM/ALK- and JunB downregulation were similar implicating that NPM/ALK inhibition and JunB suppression were connected. Most recently it was shown that JunB and c-Jun are transcription factors of PDGF-R $\beta$ (33). PDGF-R $\beta$, a receptor tyrosine kinase, which plays an important role in proliferation and differentiation (51) is overexpressed in ALCL causing the vascularization and progression of this lymphoma (33) and therefore, correlates with bad prognosis. The treatment of a terminal ALCL patient with a $\mathrm{t}(2 ; 5)(\mathrm{p} 23 ; \mathrm{q} 35)$ translocation with imatinib, which inhibits the tyrosine kinase activity of PDGF-R $\beta$, caused complete remission within 14 days and this further confirms that the downstream effectors of 
NPM/ALK are JunB and PDGF-R $\beta$ (33). Thus, the inhibition of NPM/ALK by the N. lobata extract most likely caused the downregulation of JunB and with some delay the decrease of PDGF-R $\beta$ expression. The inhibition of NPM/ALK expression by $N$. lobata was specific, because the extract of $C$. morifolia or vincristine (which is used for ALCL treatment) did not affect NPM/ALK levels. N. lobata was toxic for malignant cells, but not for normal HLFs. In mice, oral and intra-peritoneal administration of $500 \mathrm{mg} / \mathrm{kg}$ of the water, ethanol and dichloromethane extract every $48 \mathrm{~h}$ for three weeks did not exhibit sub-acute toxicity and oral dosages up to $5 \mathrm{~g} / \mathrm{kg}$ did not exhibit acute toxicity (52). This highlights the specificity of this $N$. lobata extract against malignant cells.

\section{Acknowledgements}

We wish to thank Toni Jäger for preparing the images. This study was supported by the Funds for Innovative and Interdisciplinary Cancer Research to M.F.-S. and G.K and the Hochschuljubiläumsstiftung der Stadt Wien to G.K. H.D. is supported by the Herzfelder Family Foundation and the NÖ Forschungs- und Bildungsges.m.b.H. (NFB).

\section{References}

1. Koehn FE and Carter GT: The evolving role of natural products in drug discovery. Nat Rev Drug Discov 4: 206-220, 2005.

2. Cragg GM and Newman DJ: Natural Product Sources of Drugs: Plants, Microbes, Marine Organisms, and Animals. Comprehensive Medicinal Chemistry II. Chapter 1.08: 355-403, 2007.

3 Gidding CE, Kellie SJ, Kamps WA and de Graaf SS: Vincristine revisited. Crit Rev Oncol Hematol 29: 267-287, 1999.

4. Arvigo R and Balick M: Rainforest Remedies. 2nd edition. Lotus Press, Twin Lakes, WI, 1998.

5. Berger I, Passreiter CM, Cáceres A and Kubelka W: Antiprotozoal activity of Neurolaena lobata. Phytother Res 15: 327-330, 2001

6. Gupta MP, Solis NG, Avella ME and Sanchez C: Hypoglycemic activity of Neurolaena lobata (L.) R. Br J Ethnopharmacol 10 323-327, 1984.

7. Bedoya LM, Alvarez A, Bermejo M, González N, Beltrán M, Sánchez-Palomino S, Cruz SM, Gaitán I, del Olmo E, Escarcena R, García PA, Cáceres A, San Feliciano A and Alcamí J: Guatemalan plants extracts as virucides against HIV-1 infection. Phytomedicine 15: 520-524, 2008.

8. Passreiter CM, Wendisch D and Gondol D: Sesquiterpene lactones from Neurolaena lobata. Phytochemistry 39: 133-137, 1995.

9. François G, Passreiter C, Woerdenbag $\mathrm{H}$ and van Looveren M: Antiplasmodial activities and cytotoxic effects of aqueous extracts and sesquiterpene lactones from Neurolaena lobata. Planta Med 62: 126-129, 1996.

10. Berger I, Barrientos AC, Cáceres A, Hernández M, Rastrelli L, Passreiter CM and Kubelka W: Plants used in Guatemala for the treatment of protozoal infections: II. Activity of extracts and fractions of five Guatemalan plants against Trypanosoma cruzi. J Ethnopharmacol 62: 107-115, 1998.

11. Morris SW, Kirstein MN, Valentine MB, Dittmer KG, Shapiro DN, Saltman DL and Look AT: Fusion of a kinase gene, ALK, to a nucleolar protein gene, NPM, in non-Hodgkin's lymphoma. Science 263: 1281-1284, 1994.

12. Stein H, Foss HD, Dürkop H, Marafioti T, Delsol G, Pulford K, Pileri S and Falini B: CD30(+) anaplastic large cell lymphoma: a review of its histopathologic, genetic, and clinical features. Blood 96: 3681-3695, 2000.

13. Piva R, Chiarle R, Manazza AD, Taulli R, Simmons W, Ambrogio C, D'Escamard V, Pellegrino E, Ponzetto C, Palestro G and Inghirami G: Ablation of oncogenic ALK is a viable therapeutic approach for anaplastic large-cell lymphomas. Blood 107: 689-697, 2006
14. Simonitsch I, Polgar D, Hajek M, Duchek P, Skrzypek B, Fassl S, Lamprecht A, Schmidt G, Krupitza G and Cerni C: The cytoplasmic truncated receptor tyrosine kinase ALK homodimer immortalizes and cooperates with ras in cellular transformation. FASEB J 15: 1416-1428, 2001.

15. Meadows AT, Friedman DL, Neglia JP, Mertens AC, Donaldson SS, Stovall M, Hammond S, Yasui Y and Inskip PD: Second neoplasms in survivors of childhood cancer: findings from the Childhood Cancer Survivor Study cohort. J Clin Oncol 27: 2356-2362, 2009.

16. Reiter A: Diagnosis and treatment of childhood non-Hodgkin lymphoma. Hematology Am Soc Hematol Educ Program, pp285296, 2007.

17. Freed $\mathbf{J}$ and Kelly KM: Current approaches to the management of pediatric Hodgkin lymphoma. Paediatr Drugs 12: 85-98, 2010.

18. Palmer RH, Vernersson E, Grabbe C and Hallberg B: Anaplastic lymphoma kinase: signalling in development and disease. Biochem J 420: 345-361, 2009.

19. Hallberg B and Palmer RH: Crizotinib - latest champion in the cancer wars? N Engl J Med 363: 1760-1762, 2010.

20. Maier S, Strasser S, Saiko P, Leisser C, Sasgary S, Grusch M, Madlener S, Bader Y, Hartmann J, Schott H, Mader RM, Szekeres T, Fritzer-Szekeres M and Krupitza G: Analysis of mechanisms contributing to AraC-mediated chemoresistance and re-establishment of drug sensitivity by the novel heterodinucleoside phosphate 5-FdUrd-araC. Apoptosis 11: 427-440, 2006.

21. Strasser S, Maier S, Leisser C, Saiko P, Madlener S, Bader Y, Bernhaus A, Gueorguieva M, Richter S, Mader RM, WesierskaGadek J, Schott H, Szekeres T, Fritzer-Szekeres M and Krupitza G: 5-FdUrd-araC heterodinucleoside re-establishes sensitivity in 5-FdUrd- and AraC-resistant MCF-7 breast cancer cells overexpressing ErbB2. Differentiation 74: 488-498, 2006.

22. Fassl S, Leisser C, Huettenbrenner S, Maier S, Rosenberger G, Strasser S, Grusch M, Fuhrmann G, Leuhuber K, Polgar D, Stani J, Tichy B, Nowotny C and Krupitza G: Transferrin ensures survival of ovarian carcinoma cells when apoptosis is induced by TNFalpha, FasL, TRAIL, or Myc. Oncogene 22: 8343-8355, 2003.

23. Leisser C, Rosenberger G, Maier S, Fuhrmann G, Grusch M, Strasser S, Huettenbrenner S, Fassl S, Polgar D, Krieger S, Cerni C, Hofer-Warbinek R, deMartin R and Krupitza G: Subcellular localisation of Cdc25A determines cell fate. Cell Death Differ 11: 80-89, 2004.

24. Grusch M, Polgar D, Gfatter S, Leuhuber K, Huettenbrenner S, Leisser C, Fuhrmann G, Kassie F, Steinkellner H, Smid K, Peters GJ, Jayaram HN, Klepal W, Szekeres T, Knasmüller S and Krupitza G: Maintenance of ATP favours apoptosis over necrosis triggered by benzamide riboside. Cell Death Differ 9: 169-178, 2002.

25. Livak KJ and Schmittgen TD: Analysis of relative gene expression data using real-time quantitative PCR and the 2[-Delta Delta C(T)] method. Methods 25: 402-408, 2001.

26. Coller HA, Grandori C, Tamayo P, Colbert T, Lander ES, Eisenman RN and Golub TR: Expression analysis with oligonucleotide microarrays reveals that MYC regulates genes involved in growth, cell cycle, signaling, and adhesion. Proc Natl Acad Sci USA 97: 3260-3265, 2000.

27. Mathas S, Hinz M, Anagnostopoulos I, Krappmann D, Lietz A, Jundt F, Bommert K, Mechta-Grigoriou F, Stein H, Dörken B and Scheidereit C: Aberrantly expressed c-Jun and JunB are a hallmark of Hodgkin lymphoma cells, stimulate proliferation and synergize with NF-kappa B. EMBO J 21: 4104-4113, 2002.

28. Staber PB, Vesely P, Haq N, Ott RG, Funato K, Bambach I, Fuchs C, Schauer S, Linkesch W, Hrzenjak A, Dirks WG, Sexl V, Bergler H, Kadin ME, Sternberg DW, Kenner L and Hoefler G: The oncoprotein NPM-ALK of anaplastic large-cell lymphoma induces JUNB transcription via ERK1/2 and JunB translation via mTOR signaling. Blood 110: 3374-3383, 2007.

29. Unger C, Popescu R, Giessrigl B, Rarova L, Herbacek I, Seelinger M, Diaz R, Wallnöfer B, Fritzer-Szekeres M, Szekeres T, Frisch R, Doležal K, Strnad M, De Martin R, Grusch M, Kopp B and Krupitza G: An apolar extract of Critonia morifolia inhibits c-Myc, cyclin D1, Cdc25A, Cdc25B, Cdc25C and Akt and induces apoptosis. Int J Oncol 40: 2131-2139, 2012.

30. Slupianek A, Nieborowska-Skorska M, Hoser G, Morrione A, Majewski M, Xue L, Morris SW, Wasik MA and Skorski T: Role of phosphatidylinositol 3-kinase-Akt pathway in nucleophosmin/ anaplastic lymphoma kinase-mediated lymphomagenesis. Cancer Res 61: 2194-2199, 2001. 
31. Polgar D, Leisser C, Maier S, Strasser S, Rüger B, Dettke M, Khorchide M, Simonitsch I, Cerni C and Krupitza G: Truncated ALK derived from chromosomal translocation $\mathrm{t}(2 ; 5)(\mathrm{p} 23 ; \mathrm{q} 35)$ binds to the SH3 domain of p85-PI3K. Mutat Res 570: 9-15, 2005.

32. Cockle SM and Dean RT: The regulation of proteolysis in normal fibroblasts as they approach confluence. Evidence for the participation of the lysosomal system. Biochem J 208: 795-800, 1982

33. Laimer D, Dolznig H, Kollmann K, Vesely PW, Schlederer M, Merkel O, Schiefer AI, Hassler MR, Heider S, Amenitsch L, Thallinger C, Staber PB, Simonitsch-Klupp I, Artaker M, Lagger S, Turner SD, Pileri S, Piccaluga PP, Valent P, Messana K, Landra I, Weichhart T, Knapp S, Shehata M, Todaro M, Sexl V, Höfler G, Piva R, Medico E, Ruggeri BA, Cheng M, Eferl R, Egger G, Penninger JM, Jaeger U, Moriggl R, Inghirami G and Kenner L: PDGFR blockade is a rational and effective therapy for NPM-ALK driven lymphomas. Nat Med (In press).

34. Andrae J, Gallini R and Betsholtz C: Role of platelet-derived growth factors in physiology and medicine. Genes Dev 22: 1276-1312, 2008.

35. Jechlinger M, Sommer A, Moriggl R, Seither P, Kraut N, Capodiecci P, Donovan M, Cordon-Cardo C, Beug H and Grünert S: Autocrine PDGFR signaling promotes mammary cancer metastasis. J Clin Invest 116: 1561-1570, 2006

36. Ergin M, Denning MF, Izban KF, Amin HM, Martinez RL, Saeed S and Alkan S: Inhibition of tyrosine kinase activity induces caspase-dependent apoptosis in anaplastic large cell lymphoma with NPM-ALK (p80) fusion protein. Exp Hematol 29: 1082-1090, 2001.

37. Gridling M, Stark N, Madlener S, Lackner A, Popescu R, Benedek B, Diaz R, Tut FM, Nha Vo TP, Huber D, Gollinger M, Saiko P, Ozmen A, Mosgoeller W, De Martin R, Eytner R, Wagner KH, Grusch M, Fritzer-Szekeres M, Szekeres T, Kopp B, Frisch R and Krupitza G: In vitro anti-cancer activity of two ethno-pharmacological healing plants from Guatemala Pluchea odorata and Phlebodium decumanum. Int J Oncol 34: 1117-1128, 2009.

38. Stark N, Gridling M, Madlener S, Bauer S, Lackner A, Popescu R, Diaz R, Tut FM, Vo TP, Vonach C, Giessrigl B, Saiko P, Grusch M, Fritzer-Szekeres M, Szekeres T, Kopp B, Frisch R and Krupitza G: A polar extract of the Maya healing plant Anthurium schlechtendalii (Aracea) exhibits strong in vitro anticancer activity. Int J Mol Med 24: 513-521, 2009.

39. Madlener S,Svacinová J,Kitner M,Kopecky J,Eytner R,Lackner A, Vo TP, Frisch R, Grusch M, De Martin R, Dolezal K, Strnad M and Krupitza G: In vitro anti-inflammatory and anticancer activities of extracts of Acalypha alopecuroidea (Euphorbiaceae). Int J Oncol 35: 881-891, 2009.

40. Ozmen A, Bauer S, Gridling M, Singhuber J, Krasteva S, Madlener S, Vo TP, Stark N, Saiko P, Fritzer-Szekeres M, Szekeres T, Askin-Celik T, Krenn L and Krupitza G: In vitro antineoplastic activity of the ethno-pharmaceutical plant Hypericum adenotrichum Spach endemic to Western Turkey. Oncol Rep 22: 845-852, 2009

41. Ozmen A, Madlener S, Bauer S, Krasteva S, Vonach C, Giessrigl B, Gridling M, Viola K, Stark N, Saiko P, Michel B, Fritzer-Szekeres M, Szekeres T, Askin-Celik T, Krenn L and Krupitza G: In vitro anti-leukemic activity of the ethno-pharmacological plant Scutellaria orientalis ssp. carica endemic to western Turkey. Phytomedicine 17: 55-62, 2010.
42. Vo NT, Madlener S, Bago-Horvath Z, Herbacek I, Stark N, Gridling M, Probst P, Giessrigl B, Bauer S, Vonach C, Saiko P, Grusch M, Szekeres T, Fritzer-Szekeres M, Jäger W, Krupitza G and Soleiman A: Pro- and anticarcinogenic mechanisms of piceatannol are activated dose dependently in MCF-7 breast cancer cells. Carcinogenesis 31: 2074-2081, 2010.

43. Khan M, Giessrigl B, Vonach C, Madlener S, Prinz S, Herbaceck I, Hölzl C, Bauer S, Viola K, Mikulits W, Quereshi RA, Knasmüller S, Grusch M, Kopp B and Krupitza G: Berberine and a Berberis lycium extract inactivate Cdc25A and induce alpha-tubulin acetylation that correlate with HL-60 cell cycle inhibition and apoptosis. Mutat Res 683: 123-130, 2010.

44. Bauer S, Singhuber J, Seelinger M, Unger C, Viola K, Vonach C, Giessrigl B, Madlener S, Stark N, Wallnofer B, Wagner KH, Fritzer-Szekeres M, Szekeres T, Diaz R, Tut F, Frisch R, Feistel B, Kopp B, Krupitza G and Popescu R: Separation of antineoplastic activities by fractionation of a Pluchea odorata extract. Front Biosci (Elite Ed) 3: 1326-1336, 2011.

45. Madlener S, Saiko P, Vonach C, Viola K, Huttary N, Stark N, Popescu R, Gridling M, Vo NT, Herbacek I, Davidovits A, Giessrigl B, Venkateswarlu S, Geleff S, Jäger W, Grusch M, Kerjaschki D, Mikulits W, Golakoti T, Fritzer-Szekeres M, Szekeres T and Krupitza G: Multifactorial anticancer effects of digalloyl-resveratrol encompass apoptosis, cell-cycle arrest, and inhibition of lymphendothelial gap formation in vitro. Br J Cancer 102: 1361-1370, 2010.

46. Kerjaschki D, Bago-Horvath Z, Rudas M, Sexl V, Schneckenleithner C, Wolbank S, Bartel G, Krieger S, Kalt R Hantusch B, Keller T, Nagy-Bojarszky K, Huttary N, Raab I, Lackner K, Krautgasser K, Schachner H, Kaserer K, Rezar S, Madlener S, Vonach C, Davidovits A, Nosaka H, Hämmerle M, Viola K, Dolznig H, Schreiber M, Nader A, Mikulits W, Gnant M, Hirakawa S, Detmar M, Alitalo K, Nijman S, Offner F, Maier TJ, Steinhilber D and Krupitza G: Lipoxygenase mediates invasion of intrametastatic lymphatic vessels and propagates lymph node metastasis of human mammary carcinoma xenografts in mouse. J Clin Invest 121: 2000-2012, 2011.

47. Passreiter CM: Pyrrolizidine alkaloids from Neurolaena lobata. Biochem Sys Ecol 26: 839-843, 1998.

48. Ghantous A, Gali-Muhtasib H, Vuorela H, Saliba NA and Darwiche N: What made sesquiterpene lactones reach cancer clinical trials? Drug Discov Today 15: 668-678, 2010.

49. Zhang S, Won YK, Ong CN and Shen HM: Anti-cancer potential of sesquiterpene lactones: bioactivity and molecular mechanisms. Curr Med Chem Anticancer Agents 5: 239-249, 2005.

50. Hsu FY, Johnston PB, Burke KA and Zhao Y: The expression of $\mathrm{CD} 30$ in anaplastic large cell lymphoma is regulated by nucleophosmin-anaplastic lymphoma kinase-mediated JunB level in a cell type-specific manner. Cancer Res 66: 9002-9008, 2006.

51. Gotzmann J, Fischer AN, Zojer M, Mikula M, Proell V, Huber H, Jechlinger M, Waerner T, Weith A, Beug H and Mikulits W: A crucial function of PDGF in TGF-beta-mediated cancer progression of hepatocytes. Oncogene 25: 3170-3185, 2006.

52. Cáceres A, López B, González S, Berger I, Tada I and Maki J: Plants used in Guatemala for the treatment of protozoal infections. I. Screening of activity to bacteria, fungi and American trypanosomes of 13 native plants. J Ethnopharmacol 62: 195-202, 1998. 